\title{
PELATIHAN KEBERSYUKURAN UNTUK MENINGKATKAN KUALITAS HIDUP PADA WANITA DISABILITAS FISIK
}

\author{
Desta Israwanda 1 \\ Siti Urbayatun \\ Elli Nur Hayati \\ Program Studi Psikologi Profesi (S2), Universitas Ahmad Dahlan, \\ Yogyakarta
}

\begin{abstract}
This study examines the effect of gratitude training to improve the quality of life in women with physical disabilities. Participans of this study were 30 participants, there are 15 participants in each group. The data were analyzed using mixed design anova.The result showed a very significant difference in quality of life's score at pretest, posttest, and follow up between the experimental and controlled group ( $F=56,586, p=0,000(p<0,05))$.In addition, there was significant changes in quality of life's score at experimental group ( $M D=-15,467$ and $p=0,000$.Those findings indicate that there was increase in the level quality of life in the experimental group.Furthermore,gratitude training contributed $84,3 \%$ to the increase quality of life.of women with physical disabilities.
\end{abstract}

Keywords: Gratitude training, quality of life, women with physical disabilities

\begin{abstract}
Abstrak. Penelitian ini bertujuan mengetahui pengaruh pelatihan kebersyukuran terhadap peningkatan kualitas hidup wanita penyandang disabilitas fisik. Rancangan penelitian yang akan digunakan adalah pretest-posttest-follow up control group design. Subjek penelitian sebanyak 30 orang terbagi ke dalam 15 orang kelompok eksperimen dan 15 orang kelompok kontrol. Analisis data menggunakan anava mixed design untuk melihat perbedaan skor dalam kelompok (pretest-posttest-follow up) serta perbedaan skor antar kelompok (eksperimen dan kontrol). Hasil analisis menunjukkan perbedaan skor yang sangat signifikan pada pretest-posttest-follow up antar kedua kelompok $(\mathrm{F}=56,586$; dan $\mathrm{p}=0,000(0<0,01))$. Hasil analisis juga menunjukkan bahwa kelompok eksperimen mengalami peningkatan kualitas hidup setelah diberikan pelatihan kebersyukuran dibandingkan dengan kelompok kontrol yang tidak diberikan intervensi hingga pada tahap follow up yang dilakukan pada kedua kelompok.
\end{abstract}

Kata kunci : Disabilitas fisik, kualitas hidup, pelatihan kebersyukuran

\footnotetext{
${ }^{1}$ Korespondensi mengenai artikel dapat melalui : destaisra@gmail.com
} 
Jumlah penyandang disabilitas di Indonesia terus mengalami peningkatan setiap tahunnya. Penyandang disabilitas kini menjadi salah satu masalah sosial yang membutuhkan perhatian pemerintah dan semua komponen bangsa Indonesia. Penyandang disabilitas juga mempunyai hak dan kewajiban yang sama dalam segala aspek kehidupan dan penghidupan. Populasi penyandang disabilitas di dunia sekitar 15\% dari total penduduk yang ada. Kurang lebih ada satu milyar orang penyandang disabilitas yang tergolong berat sehingga membatasi partisipasi mereka di dalam keluarga, masyarakat, dan kehidupan politik (WHO, 2014). Sebanyak 80\% dari mereka tinggal di negara-negara yang tingkat ekonominya menengah ke bawah, dimana akses pelayanan kesehatan dan sosial masih terbatas untuk semua warga negara (WHO, 2014).

Jumlah penyandang disabilitas di Indonesia memiliki potensi mengalami peningkatan terutama disabilitas fisik, hal ini disebabkan tingginya faktor risiko yang dapat menyebabkan terjadinya disabilitas di Indonesia. Potensi risiko tersebut antara lain karena adanya konflik sosial yang terjadi di beberapa daerah maupun potensi bencana alam yang dapat terjadi seperti gempa bumi, tsunami, tanah longsor dan sebagainya (Sukaton, 2011). Badan Pusat Statistik juga menerbitkan survei ketenagakerjaan nasional dengan estimasi jumlah penyandang disabilitas di Indonesia $12,15 \%$. Sama seperti tahun sebelumnya jumlah penyandang disabilitas perempuan lebih banyak yakni sebesar 53,37\% dan laki-laki sebesar 46,63\% (Badan Pusat Statistik, 2016)

Data tersebut sama dengan hasil susenas pada tahun 2012, yang dilaksanakan oleh Badan Pusat Statistik (BPS), menyebutkan jumlah penyandang disabilitas di Indonesia sebanyak 6.008.661 orang, diantaranya 1,780,200 orang adalah penyandang disabilitas netra, 472.855 orang disabilitas rungu wicara, 402.817 orang penyandang disabilitas grahita/ intelektual, 616.387 orang penyandang disabilitas tubuh, 170.120 orang penyandang disabilitas yang sulit mengurus diri sendiri dan sekitar 2.401 .592 orang mengalami disabilitas ganda. Presentase perempuan penyandang disabilitas secara nasional sebesar 2,55\% terhadap total penduduk Jika dibandingkan dengan perempuan, presentase laki-laki penyandang disabilitas relatif lebih rendah.

Penyandang disabilitas fisik biasanya mempunyai hambatan fisik/ mobilitas, mempunyai masalah mental psikologis, rasa rendah diri, kurang percaya diri, isolatif, mengalami kecanggungan dalam melaksanakan fungsi sosialnya. Para penyandang disabilitas fisik kerap kali terisolir secara sosial dan menghadapi diskriminasi dalam akses atas kesehatan dan layanan-layanan lainnya seperti pendidikan dan pekerjaan. Kinasih (2010) berpendapat bahwa keterbatasan fungsi fisik mengakibatkan penyandang disabilitas kesulitan mengakses pekerjaan karena dianggap kurang produktif. Hal tersebut berdampak negatif bagi penyandang disabilitas seperi kehilangan peran, kemandirian, status dan stabilitas keuangan (Bastaman, 2007).

Hasil wawancara yang dilakukan terhadap individu dengan disabilitas fisik di sentra advokasi perempuan difable dan anak (SAPDA), diketahui wanita yang menyandang disabilitas fisik/cacat tubuh sering sekali diperlakukan tidak sesuai dengan norma-norma yang berlaku di masyarakat. Wanita dengan disabilitas fisik juga banyak yang menjadi korban pelecehan seksual, dan tidak dipercayai untuk melakukan pekerjaan karena dianggap tidak pantas dan sering dihina. 
Hal tersebut membuat mereka sering menyendiri tidak ingin keluar rumah dan berinteraksi dengan orang lain. Selain itu, kecemasan dan kekhawatiran akan hubungan pernikahan di masa yang akan datang membuat para wanita dengan disabilitas fisik sering merasa minder dan tidak berdaya.

Mobilitas yang terganggu serta kondisi psikologis terguncang yang dialami penyandang disabilitas tubuh/cacat fisik membuat kualitas hidup individu tersebut juga menurun atau berkurang. Hasil penelitian Handayani \& Dewi (2016) yang menunjukkan adaya perubahan aktivitas sehari-hari, pola komunikasi, aktivitas kerja, hubungan sosial, istirahat dan rekreasi serta kondisi psikologis pada penderita atau keluarga pasca stroke yang memerlukan keluarga atau orang lain dalam membantu kegiatan sehari-hari karena keterbatasan yang dimiliki.

Menurut lembaga WHOQoL Group (Power, 2003), kualitas hidup merupakan persepsi individu dilihat dari posisi kehidupan individu dalam konteks budaya dan sistem nilai dimana individu hidup memiliki tujuan, harapan, standarisasi dan rasa kekhawatiran. Hal ini berpengaruh pada kesehatan fisik, keadaan psikologis, tingkat kepuasan, hubungan sosial dan hubungan dengan lingkungan. Sarafino \& Smith (2014) mengartikan kualitas hidup adalah penilaian individu tentang peningkatan yang dialami individu selama hidup berkaitan dengan kemampuan dalam beraktifitas, energi atau ketidaknyamanan, perasaan positif dan negatif kontrol pribadi, hubungan interpersonal, kenyamanan beraktivitas, materi pertumbuhan pribadi dan intelektual.

Berdasarkan definisi kualitas hidup yang dibuat oleh WHOQL (Power, 2003) terdapat domain-domain yang merupakan bagian penting untuk mengetahui kualitas hidup individu. Domain tersebut adalah (1) kesehatan fisik, dapat mempengaruhi kemampuan individu untuk melakukan aktivitas. Aktivitas yang dilakukan individu akan memberikan pengalaman-pengalaman baru yang merupakan modal perkembangan ke tahap selanjutnya. (2) psikologis, terkait dengan keadaan mental individu. Keadaan mental mengarah pada mampu atau tidaknya individu menyesuaikan diri terhadap berbagai tuntutan perkembangan sesuai dengan kemampuannya, baik tuntutan dari dalam diri maupun dari luar dirinya (3) sosial, hubungan antara dua individu atau lebih yang dilihat dari tingkah laku individu tersebut akan saling mempengaruhi, mengubah, atau memperbaiki tingkah laku individu lainnya dan (4) lingkungan. yaitu tempat tinggal individu, termasuk di dalamnya keadaan, ketersediaan tempat tinggal untuk melakukan segala aktivitas kehidupan, termasuk di dalamnya adalah sarana dan prasarana yang dapat menunjang kehidupan.

Faktor-faktor yang dapat mempengaruhi kualitas hidup menurut penelitian terdahulu adalah rasa syukur yang diungkapkan hasil Penelitian Emmons \& McCullough (2003) bahwa rasa syukur membuat kehidupan individu lebih baik dan adanya pandangan yang optimis kedepannya. Penelitian yang dilakukan Ishak (2007) menyebutkan bahwa adanya hubungan rasa syukur dengan kesejahteraan psikologis yang akan meningkatkan kualitas hidup individu.

Penyandang disabilitas fisik sangat membutuhkan adanya pengakuan sebagai individu dan makhluk sosial yang memiliki kemampuan dan potensi yang tidak jauh berbeda. Mobilitas yang terganggu serta kondisi psikologis yang terguncang dikarenakan keadaan disabilitas fisik yang dialami penyandang disabilitas tubuh/cacat fisik membuat kualitas hidup individu tersebut juga menurun atau berkurang. Hasil penelitian Handayani \& Dewi (2016) yang menunjukkan adanya perubahan aktivitas sehari-hari, pola komunikasi, 
aktivitas kerja, hubungan sosial, istirahat dan rekreasi serta kondisi psikologis pada penderita atau keluarga pasca stroke yang memerlukan keluarga atau orang lain dalam membantu kegiatan sehari-hari karena keterbatasan yang dimilikinya. Peningkatan kualitas hidup pada wanita penyandang disabilitas fisik merupakan hal yang penting. Menurut Alexander (2014) bahwa wanita lebih rentan mengalami gangguan psikis atau stres psikologis dibandingkan dengan laki-laki terlebih bagi wanita yang mengalami disabilitas.

Emmons \& McCullough (2003) menyatakan kebersyukuran merupakan konstruksi kognitif, emosi dan perilaku kebersyukuran sebagai konstruksi kognitif ditunjukkan dengan mengakui kemurahan dan kebaikan hati atas berkah yang telah diterima dan fokus terhadap hal positif di dalam dirinya saat ini. Sebagai konstruksi emosi, kebersyukuran ditandai dengan kemampuan mengubah respons emosi terhadap suatu peristiwa sehingga menjadi lebih bermakna.

Kebersyukuran menurut pandangan Islam menyatakan lebih merefleksikan nilai kebaikan yang diterima kepada diri sendiri dan Allah sebagai pencipta. Hablum minallah adalah fokus utamanya dalam melakukan kebaikan pada orang lain merupakan wujud dari beribadah kepada Allah SWT, yang diantaranya mengharuskan menolong orang lain dan hormat pada orang tua (Hambali \& Fahmi, 2015). Kebersyukuran memiliki manfaat yang tidak hanya dari sisi psikologis, tetapi juga turut meningkatkan derajat kesehatan fisik seorang misalnya orang-orang yang memiliki penyakit gagal jantung atau lainnya (Ouweneel, Le Blanc \& Scahaufeli, 2014).

Beberapa penelitian (intervensi) yang telah dilakukan sebelumnya tentang sabar oleh Faizah (2018) menyebutkan bahwa pelatihan sabar dapat meningkatkan kualitas hidup pada penderita disabilitas fisik. Hasil penelitian Putri, Hayati \& Urbayatun (2017) mengatakan bahwa pelatihan kebersyukuran terbukti efektif dalam memberikan perubahan yang positif pada kualitas hidup lansia. Penelitian lain dilakukan Dewanto \& Retno (2015) tentang intervensi kebersyukuran dan kesejahteraan penyandang disabilitas fisik. Hasil penelitian menunjukkan bahwa intervensi yang diberikan dapat meningkatkan kesejahteraan hidup secara signifikan.

Individu yang sering merasakan dan mengungkapkan rasa terimakasih akan lebih mampu merasakan emosi positif dan mengurangi emosi negatif seperti stres dalam aspek kehidupannya. Individu itu dapat memandang permasalahan hidup menjadi lebih positif serta dapat lebih bahagia dan tenang hingga dapat menjalin kehidupan sosial yang lebih baik. Sejalan dengan penelitian Froh, Seffick, \& Emmons (2008) bahwa individu yang sering merasakan dan mengungkapkan rasa terima kasih akan lebih optimis dan energik ataupun membantu orang lain daripada orang yang tidak mengalami rasa bersyukur terhadap kualitas hidupnya.

Froh, Kashdan \& Ozimikowski (2009) menuliskan bahwa pemaknaan tentang manfaat bersyukur adalah tentang penerimaan secara ikhlas terhadap segala sesuatu yang dianggap sebagai pemberian Allah SWT, sehingga ketika merasa bersyukur maka akan dapat menimbulkan emosi positif dalam diri seseorang. Wood, Joseph\& Maltby (2009) menyatakan bersyukur dapat meningkatkan kesejahteraan psikologis berupa penguasaan terhadap lingkungan, pertumbuhan pribadi, hubungan posiif, tujuan hidup dan penerimaan diri.

Penelitian ini bertujuan untuk menguji pengaruh pelatihan kebersyukuran dalam meningkatkan kualitas hidup pada wanita penyandang disabilitas fisik. Penelitian ini juga diharapkan dapat memberikan sumbangan pengembangan 
pengetahuan di bidang psikologi secara khusus pada bidang psikologi klinis, sosiologi dan kesehatan. Pelatihan kebersyukuran dapat dijadikan alternatif untuk meningkatkan kualitas hidup pada wanita penyandang disabilitas fisik.

Hipotesis yang diajukan dalam penelitian ini adalah adanya pengaruh intervensi kebersyukuran untuk meningkatkan kualitas hidup wanita penyandang disabilitas fisik kelompok yang diberikan perlakuan lebih tinggi kualitas hidupnya dibandingkan dengan kelompok yang tidak diberikan perlakuan.

\section{METODE}

\section{Rancangan Penelitian}

Penelitian ini menggunakan desain eksperimen dengan model rancangan penelitian yang akan digunakan adalah pretest-posttest- follow up control group design. Penelitian ini menggunakan dua kelompok yaitu kelompok eksperimen dan kelompok kontrol.

Tabel. 1, Rancangan Penelitian

\begin{tabular}{llllll}
\hline & Kelompok & Prates & Perlakuan & Pascates & Tindaklanjut \\
\hline \multirow{2}{*}{ RA } & Eksperimen & 01 & $\mathrm{X}$ & 02 & 03 \\
& Kontrol & 01 & $-\mathrm{X}$ & 02 & 03 \\
\hline
\end{tabular}

Keterangan :

$01 \quad$ : Skor skala kualitas hidup pada saat prates

02 : Skor skala kualitas hidup pada saat pascates

O3 : Skor skala kualitas hidup pada saat tindaklanjut

$\mathrm{X}$ : Perlakuan berupa pelatihan kebersyukuran pada kelompok eksperimen

-X $\quad$ : Tidak diberikan perlakuan pada kelompok control

\section{Definisi Operasional}

Kualitas hidup adalah penilaian individu terhadap posisi individu di dalam kehidupan, dalam konteks budaya dan sistem nilai di mana individu hidup berkaitan dengan tujuan individu, harapan, standar serta apa yang menjadi perhatian individu. Kualitas hidup dalam peneitian ini diperoleh dari skala kualitas hidup berdasarkan aspek-aspek kuaitas hidup dari WHO (2004) yang sudah diadaptasi dengan Bahasa Indonesia yaitu kesehatan fisik, kesejahteraan psikologis, hubungan sosial dan lingkungan. Skor skala kualitas hidup bergerak dari satu sampai lima. Semakin tinggi skor pada skala kualitas hidup menunjukkan semakin tinggi.
Pelatihan kebersyukuran merupa-kan serangkaian pelatihan yang dirancang untuk membantu wanita dengan disabilitas fisik untuk dapat mengidentifikasi kelebihan yang dimiliki, kesuksesan dan kegagalan dari pengalaman hidup serta dapat menerapkan strategi bersyukur di aktivitas sehari-hari. Pelatihan kebersyukuran yang akan dilaksanakan selama tiga kali pertemuan dan masing-masing pertemuan dilaksanakan selama 100-120 menit. Modul pelatihan kebersyukuran yang diberikan menggunakan modul yang dibuat dan dikembangkan Putri, Hayati \& Urbayatun (2017) berdasarkan aspek-aspek kebersyukuran dari al-Jauziyah (2010) yang diantaranya adalah mengungkapkan perasaan dan harapan, mengucapkan dan melakukan perbuatan syukur, melakukan refleksi diri serta kesadaran akan hakikat 
hidup bahwa segala yang dimiliki berasal dari Allah SWT. Adapun penyesuaian yang dilakukan dalam modul yang akan digunakan adalah menghilangkan kekhususan pada lansia, serta menyerderhanakan penggunaan bahasa sesuai dengan pemahaman dan bahasa yang dapat diterima oleh wanita dengan disabilitas fisik, menghilangkan sesi hakikat hidup serta mengganti video yang sebelumnya digunakan untuk memotivasi lansia menjadi video yang berkaitan dengan wanita difabel. Intervensi akan diberikan pada kelompok eksperimen.

\section{Subjek Penelitian}

Pengambilan subjek dalam penelitian ini menggunakan teknik purposive sampling. Subjek yang akan terlibat dalam penelitian ini yaitu wanita dengan disabilitas fisik berjumlah 30 orang (masing-masing 15 orang tiap kelompok) setelah sebelumnya dilakukan screening dan memenuhi persyaratan sebagai peserta. Subjek yang mendapatkan skor sedang (skor 56-75) dan rendah (skor 0-55) pada pengukuran kualitas hidup WHOQOL-BREF akan terlibat dalam penelitian dan dijadikan sebagai kelompok eksperimen dan diberikan pelatihan kebersyukuran.

Variabel tergantung dalam penelitian ini adalah kualitas hidup dan variabel bebas adalah pelatihan kebersyukuran. Metode pengumpulan data dalam penelitian ini menggunakan skala kualitas hidup dari WHOQL BREF. Alat ukur ini reliabel dengan $\alpha=0,89-0,95$ dan indeks daya beda aitem dengan $r=0,66-0,87$. Alat ukur tersebut digunakan untuk melihat keadaan subjek sebelum diberikan perlakuan dan setelah hingga tahap tindak lanjut pemberian perlakuan yakni pelatihan kebersyukuran

\section{Prosedur dan Analisis Data}

Prosedur penelitian terdiri dari tiga tahap yaitu persiapan, pelaksanaan, dan analisis. Tahap persiapan diawali dengan pemilihan subjek sesuai dengan kriteria, Subjek diberikan alat ukur WHOQL BREF untuk melihat keadaan awal kualitas hidup pada wanita dengan disabilitas fisik, kegiatan ini disebut sebagai prates. Tahap kedua yaitu pelaksanaan intervensi dimana subjek dibagi dalam kelompok eksperimen dan kelompok kontrol, kelompok eksperimen akan mendapat perlakuan berupa pelatihan kebersyukuran untuk meninggkatkan kualitas hidup. Tahap ketiga yaitu analisis data untuk melihat perubahan dan perbedaan tingkat kategorisasi kualitas hidup pada wanita dengan disabilitas fisik pada kelompok eksperimen dan kelompok kontrol. Uji hipotesis dalam penelitian ini adalah analisis varians campuran (mixed design anova). Anava campuran menggunakan dua sub-analisis, yaitu within subject test dan between subject test, within subject test adalah pengujian perbedaan skor dalam satu kelompok (prates, pascates \& tindaklanjut) serta between subject test adalah pengujian perbedaan skor antara kelompok (eksperimen dan kontrol) (Widhiarso, 2010).

\section{HASIL PENELITIAN}

\section{Deskriptif Data Penelitian}

Berdasarkan hasil penelitian diperoleh deskriptif data statistik kualitas hidup kelompok eksperimen dan kelompok kontrol. Adapun Data statistik kedua kelompok subjek dapat dilihat pada Tabel 2 berikut ini. 
Tabel 2. Data Statistik Deskriptif Kualitas Hidup Kelompok Eksperimen dan Kelompok Kontrol

\begin{tabular}{cccccccccc}
\hline Kelompok & Pengukuran & \multicolumn{3}{c}{ Skor Hipotetik } & \multicolumn{3}{c}{ Skor Empirik } \\
\cline { 3 - 9 } & & Mean & SD & Min & Max & Mean & SD & Min & Max \\
\hline Kelompok & Prates & 78 & 17,33 & 26 & 130 & 57,20 & 5,735 & 49 & 67 \\
Eksperimen & Pascates & 78 & 17,33 & 26 & 130 & 73,27 & 4,636 & 65 & 79 \\
& Tindaklanjut & 78 & 17,33 & 26 & 130 & 78,40 & 5,604 & 68 & 88 \\
Kelompok & Prates & 78 & 17,33 & 26 & 130 & 53,27 & 3,712 & 46 & 57 \\
Kontrol & Pascates & 78 & 17,33 & 26 & 130 & 53,60 & 4,085 & 46 & 60 \\
& Tindaklanjut & 78 & 17,33 & 26 & 130 & 54,53 & 3,292 & 47 & 60 \\
\hline
\end{tabular}

Berdasarkan Tabel 2 di atas diketahui bahwa rata-rata kualitas hidup wanita dengan disabilitas fisik yang mendapatkan intervensi (kelompok eksperimen) mengalami peningkatan. Rata-rata kualitas hidup wanita dengan disabilitas fisik (kelompok eksperimen) pada saat pre intervention adalah 57,20 dan pada saat post intervention adalah 73,27 . Rata-rata kualtas hidup wanita dengan disabilitas fisik yang tidak mendapatkan intervensi pada saat pre intervention adalah 53,27 dan pada saat post intervention adalah 53,60.

Berdasarkan data statistik deskriptif menunjukkan bahwa sebelum dilakukan intervensi pelatihan kebersyukuran, tingkat kualitas hidup wanita dengan disabilitas fisik pada kelompok eksperimen lebih besar bila dibandingkan dengan kelompok kontrol yaitu 57,20 sedangkan tingkat kualitas hidup wanita dengan disabilitas fisik pada kelompok kontrol adalah 53,27. Setelah diberikan intervensi berupa pelatihan kebersyukuran terjadi peningkatan pada kualitas hidup kelompok eksperimen menjadi 73,27 dan kelompok kontrol 53,60. Hal ini menunjukkan bahwa rata-rata kualitas hidup wanita dengan disabilitas fisik mengalami peningkatan skor 19,67 pasca inervensi pelatihan kebersyukuran.

\section{Uji Asumsi}

Sebelum dilakukan uji hipotesis dilakukan uji asumsi terlebih dahulu berupa uji normalitas dan uji homogenitas. Paparan hasil uji normalitas dapat dilihat pada Tabel 3 berikut.

Tabel 3. Uji Normalitas

\begin{tabular}{lccl}
\hline & K-S-Z & Asymp. Sig. 2 tailed & Deskripsi \\
\hline Pre_KE & 0,511 & 0,956 & Normal \\
Pre_KK & 0,825 & 0,504 & Normal \\
Post_KE & 0,732 & 0,658 & Normal \\
Post_KK & 0,678 & 0,748 & Normal \\
Follow_KE & 0,537 & 0,935 & Normal \\
Follow_KK & 0,654 & 0,785 & Normal \\
\hline
\end{tabular}

Berdasarkan Tabel 3 di atas, dapat diperoleh hasil bahwa seluruh fase pengambilan data terkait skala kualitas hidup pada prates $(\mathrm{p}=0,956)$, pascates $(\mathrm{p}=0,658)$ dan tindaklanjut $(\mathrm{p}=0,935)$ pada kelompok eksperimen dan prates $(\mathrm{p}=0,504)$, pascates $(\mathrm{p}=0,748)$ dan tindaklanjut $(\mathrm{p}=0,785)$ pada kelompok kontrol terdistribusi normal dengan signifikansi $\quad(p>0,05) . \quad$ Selanjutnya dilanjutkan pada uji homegenitas yang dapat dilihat pada Tabel 4 berikut. 
Tabel 4. Uji Homogenitas

\begin{tabular}{lccc}
\hline & F & Sig & Deskripsi \\
\hline PreKE_PreKK & 4.022 & 0,055 & Homogen \\
PostKE_Post_KK & 1,740 & 0,198 & Homogen \\
FollowKE_FollowKK & 2,959 & 0,096 & Homogen \\
\hline
\end{tabular}

Berdasarkan Tabel 4 di atas, dapat diperoleh hasil uji homogenitas pretest antara kelompok eksperiman dan kelompok kontrol dengan metode levene statistic menunjukkan hasil data homogen dengan nilai $\mathrm{F}$ sebesar 4,022 dan taraf signifikansi 0,055 ( $\mathrm{p}>0,05)$, posttest antara kelompok eksperiman dan kelompok kontrol dengan metode levene statistic menunjukkan hasil data homogen dengan nilai $\mathrm{F}$ sebesar 0,066 dan taraf signifikansi $0,798 \quad(p>0,05)$ sehingga data dikatakan homogen.

\section{Uji Hipotesis}

Hipotesis dalam penelitian ini adalah kualitas hidup kelompok yang diberikan perlakuan pelatihan kebersyukuran lebih tinggi daripada kelompok yang tidak diberikan perlakuan pelatihan kebersyukuran. Analisis data yang digunakan untuk menguji hipotesis tersebut dilakukan dengan menggunakan uji statistik mixed design anava dengan melihat tabel test of within-subject effect. Adapun hasil uji hipotesa terdapat pada Tabel 5.

Tabel 5. Hasi Uji Interaksi

\begin{tabular}{llllllll}
\hline & Source & $\begin{array}{l}\text { Type III } \\
\text { Sum of Squares }\end{array}$ & Df & $\begin{array}{l}\text { Mean } \\
\text { Square }\end{array}$ & F & Sig & $\begin{array}{l}\text { Partial Eta } \\
\text { Square }\end{array}$ \\
\hline $\begin{array}{l}\text { Time* } \\
\text { Group }\end{array}$ & $\begin{array}{l}\text { Sphericity } \\
\text { Assumed } \\
\text { Greenhouse- }\end{array}$ & 1631.756 & 2 & 815.878 & 56.586 & 0,000 & 0,669 \\
& 1631.756 & 1.358 & 1201.329 & 56.586 & 0,000 & 0,669 \\
& $\begin{array}{l}\text { Geisser } \\
\text { Huynh-Feldt }\end{array}$ & 1631.756 & 1.454 & 1121.913 & 56.586 & 0,000 & 0,669 \\
& Lower-bound & 1631.756 & 1.000 & 1631.756 & 56.586 & 0,000 & 0,669 \\
\hline
\end{tabular}

Berdasarkan Tabel 5. pada baris time* ${ }^{*}$ roupdan sub baris Greenhouse-geisser menghasilkan $\mathrm{F}=56,586$ dengan signifikan $0=0,000(p<0,01)$ artinya terdapat interaksi antara time (prates-pascates-tindaklanjut) dan kelompok (eksperimen-kontrol). Interaksi tersebut menunjukkan bahwa perubahan skor prates, pascates hingga tindaklanjut pada kedua kelompok (eksperimen dan kontrol) adalah berbeda secara sangat signifikan. Setelah diketahui bahwa terjadi interaksi yang signifikan antara time (prates-pascates-tindaklanjut) dan kelompok (eksperimen dan kontrol), maka langkah selanjutnya adalah melihat pergerakan angka dalam skor kualitas hidup pada kelompok eksperimen dan kontrol yang dapat dilihat pada uji Pairwise Comparison dari Tabel 6 berkut ini 
Tabel 6. Hasil uji Pairwise Comparisons

\begin{tabular}{cccccc}
\hline Kelompok & (I) time & (J) time & Mean Difference (I-J) & Std.Error & Sig \\
& & & & & \\
\hline Eksperimen & 1 & 2 & -15.467 & 1.422 & 0,000 \\
& & 3 & -21.267 & 1.736 & 0,000 \\
& 2 & 1 & 15.467 & 1.422 & 0,000 \\
& & 3 & -5.800 & 0,855 & 0,000 \\
& 3 & 1 & 21.267 & 1.736 & 0,000 \\
Kontrol & 2 & 2 & 5.800 & 0,855 & 0,000 \\
& & 3 & $-0,333$ & 1.422 & 0,816 \\
& 2 & 1 & -1.267 & 1.736 & 0,472 \\
& 2 & 3 & 0,333 & 1.422 & 0,816 \\
& \multirow{2}{*}{3} & 1 & $-0,933$ & 0,855 & 0,285 \\
& & 2 & 1.267 & 1.736 & 0,472 \\
& & & 0.933 & 0,855 & 0,285 \\
\hline
\end{tabular}

Hasil uji pairwise comparisons pada Tabel 6 di atas menunjukkan bahwa peningkatan kualitas hidup pada wanita dengan disabilitas fisik kelompok eksperimen adalah sangat signifikan (MD 15.467 dan $p=0,000$ ) dimana $p<0,01$. Nilai MD negatif menunjukkan bahwa rerata pascates lebih tinggi daripada rerata prates, artinya peserta pada kelompok eksperimen mengalami peningkatan kualitas hidup. Sedangkan pada kelompok kontrol diperoleh hasil MD $=-0,333$ dan $\mathrm{p}=0,816$ (tidak signifikan) karena $p>0,05$. Hal tersebut menunjukkan bahwa peserta pada kelompok kontrol tidak mengalami peningkatan kualitas hidup secara signfikan.
Rata-rata tindaklanjut pada kelompok eksperimen lebih rendah dari pada rata-rata pascates $(\mathrm{MD}=-5800$ dan $\mathrm{p}$ $=0,000)$. Nilai MD negatif menunjukkan terjadinya peningkatan kualitas hidup pada kelompok eksperimen dari pascates menuju tindaklanjut. Berdasarkan pemaparan hasil uji parwise comparisons dapat diketahui bahwa pelatihan kebersyukuran dapat meningkatkan kualitas hidup pada wanita dengan disabilitas fisik. Peningkatan kualitas hidup tetap berlangsung hingga tiga minggu setelah intervensi. Selanjutnya sumbangan efektif intervensi pelatihan kebersyukuran terhadap peningkatan kualitas hidup wanita dengan disabilitas fisik dapat dilihat melalui hasil analisis statistik multivariate test pada Tabel 7.

Tabel 7. Hasil Uji Multivariate

\begin{tabular}{lccccccc}
\hline Kelompok & & Value & F & Hypothesis & Error df & Sig & $\begin{array}{c}\text { Partial Eta } \\
\text { Squared }\end{array}$ \\
\hline Eksperimen & Wilks'lambda & 0,157 & 72,429 & 2.000 & 27.000 & 0,000 & 0,843 \\
Kontrol & Wilks'lambda & 0,959 & 0,581 & 2.000 & 27.000 & 0,566 & 0,041 \\
\hline
\end{tabular}

Pada Tabel 7 dapat dilihat pada baris eksperimen wilks'lambda diketahui nilai partial eta squared $=0,843$. Hal ini menunjukkan bahwa pelatihan kebersyukuran memberikan kontribusi sebesar $84,3 \%$ terhadap peningkatan kualitas hidup wanita dengan disabilitas fisik. 


\section{PEMBAHASAN}

Hasil penelitian menunjukkan bahwa terdapat perbedaan yang sangat signifikan pada tingkat pencapaian kualitas hidup wanita dengan disabilitas fisik antara kelompok eksperimen yang mendapatkan intervensi dan kelompok kontrol yang tidak mendapatkan intervensi. dengan nilai $F=56,586$ dengan signifikan $0=0,000$ $(\mathrm{p}<0,01)$ artinya terdapat interaksi antara time (prates-pascates-tindaklanjut) dan kelompok (eksperimen-kontrol). Berdasarkan hasil analisis tersebut maka dapat disimpulkan bahwa pelatihan kebersyukuran yang dilakukan dapat efektif meningkatkan kualitas hidup wanita dengan disabilitas fisik.

Hasil analisis juga menunjukkan bahwa terjadi peningkatan kualitas hidup yang signifikan pada wanita dengan disabilitas fisik kelompok eksperimen sangat signifikan (MD -15.467 dan $\mathrm{p}=$ 0,000 ) dimana $p<0,01$. Nilai MD negatif menunjukkan bahwa rerata pascates lebih tinggi dariada rerata prates, artinya peserta pada kelompok eksperimen mengalami peningkatan kualitas hidup. Sedangkan pada kelompok kontrol diperoleh hasil MD $=-0,333$ dan $\mathrm{p}=0,816$ (tidak signifikan) karena $\mathrm{p}>0,05$. Hal tersebut menunjukkan bahwa peserta pada kelompok kontrol tidak mengalami peningkatan kualitas hidup secara signfikan.

Perubahan berkaitan dengan kebersyukuran yang dirasakan oleh peserta diungkapkan dengan peserta dapat mensyukuri nikmat yang diberikan oleh Allah SWT tidak hanya dengan mengucapkan kalimat syukur secara verbal ataupun lisan saja namun dapat memaknai rasa kebersyukuran yang diucapkan sehingga peserta mampu memanifestasikan rasa kebersyukuran tersebut dengan perbuatan seperti mampu menerima kekurangan yang dimiliki dan mensyukuri kelebihan yang telah diberikan Allah SWT.
Sejalan dengan penelitian Froh, Seffick, \& Emmons (2008) bahwa individu yang sering merasakan dan mengungkapkan rasa terima kasih akan lebih optimis dan energik ataupun membantu orang lain daripada orang yang tidak mengalami rasa bersyukur yang berhubungan dengan kualitas hidup. Arief \& Habibah (2005) juga mengungkapkan bahwa bersyukur dapat menumbuhkan pengalaman hidup yang positif dari pengalaman hidup atau situasi yang dihadapi, sehingga seorang dapat mengeluarkan kepuasan secara maksimal dan menikmati keadaan mereka. Bersyukur juga merupakan strategi koping sehingga dalam bersyukur individu dapat menafsirkan permasalahan hidup menjadi lebih positif.

Perubahan positif dari segi kualitas hidup yang terjadi pada wanita dengan disabilitas fisik baik secara kesehatan fisik, kesejahteraan psikologis maupun sosial juga sesuai dengan beberapa penelitian yang sudah pernah dilakukan sebelumnya. Froh, Kashdan \& Ozimikowski (2009) menuliskan bahwa pemaknaan tentang manfaat bersyukur adalah tentang penerimaan secara ikhlas terhadap segala sesuatu yang dianggap sebagai pemberian Allah SWT, sehingga ketika merasa bersyukur maka akan dapat menimbulkan emosi positif dalam diri seseorang.

Bersyukur dan berterimakasih atas kehidupan dapat menimbulkan ketenangan pikiran, kebahagiaan, kesehatan fisik serta hubungan pribadi lebih memuaskan (Emmons \& McCullough, 2003). Sesuai dengan penelitian Froh dkk (2008) diketahui bahwa pandangan kebersyukuran tidak memerlukan kehidupan yang penuh kenyamanan materi melainkan sikap bersyukur terlepas dari kondisi kehidupan. Hal tersebut senada dengan hasil penelitian ini dimana subjek penelitian mengalami perubahan positif setelah mendapatkan pelatihan kebersyukuran. Subjek penelitian 
mulai dapat mengidentifikasi makna dari setiap peristiwa baik ataupun buruk yang dialami. Romdhon, Rahmani \& Akbar (2010) dalam penelitiannya menyatakan bahwa rasa syukur dapat bersumber dari persepsi positif seseorang terhadap pengalaman yang dialaminya. Nikmat yang diberikan Tuhan tidak selalu datang dalam wujud peristiwa yang positif menurut manusia, tetapi dengan syukur seseorang diajarkan untuk tetap mengambil keuntungan atau mempunyai persepsi positif dari peristiwa yang tampaknya negatif. Romdhon, Rahmani \& Akbar (2010) juga menyatakan bahwa kebersyukuran tidak hanya berguna ketika individu mengalami atau menerima sesuatu yang menyenangkan.

Perubahan yang dialami subjek dalam penelitian ini, adalah dikarenakan adanya proses refleksi, berbagi dan diskusi antar sesama wanita disabilitas selama proses pelatihan. Shertzer \& Stone (1980) mengungkapkan bahwa intervensi yang diberikan secara kelompok adalah proses antarpribadi yang dinamis, yang terpusat pada pemikiran dan perilaku yang disadari sehingga proses yang dilakukan mengandung ciri-ciri terapeutik seperti pengungkapan pemikiran dan perasaan secara leluasa orientasi pada kenyataan, pembukaan diri mengenai seluruh perasaan mendalam yang dialami, saling percaya, saling perhatian, saling pengertian dan saling mendukung. Shertzer \& Stone (1980) juga mengungkapkan bahwa semua ciri terapuetik itu diciptakan dan dibina dalam suatu kelompok dengan cara mengemukakan kesulitan dan keprihatinan pribadi pada sesama anggota kelompok dan pada konselor/fasilitator, sehingga peserta dapat memanfaatkan suasana komunikasi antarpribadi dalam kelompok untuk meningkatkan pemahaman dan penerimaan terhadap nilai-nilai kehidupan dan segala tujuan hidup, serta untuk belajar dan/ atau menghilangkan suatu sikap dan perilaku tertentu.

Pada penelitian Jabbari, Shahidi \& Mootabi (2015) mengungkapkan bahwa intervensi berbasis kelompok berdasarkan psikologi positif dapat meningkatkan kepuasan hidup dan menurunkan depresi, kecemasan dan stres bahkan dapat mengurangi gangguan fisik pada remaja perempuan. Senada dengan penelitian Sanyata (2010) yang mendalami tentang teknik dan strategi konseling kelompok mengungkapkan bahwa intervensi yang berbasis kelompok membantu mengembangkan kepribadian, mengembangkan kemampuan interaksi sosial dan mengatasi permasalahan yang sedang dihadapi dengan melakukan sharing kepada orang lain dan perubahan perilaku berdasarkan hasil interaksi dan diskusi dapat terus bertahan pada jangka panjang.

Hasil dari intervensi yang diberikan secara kelompok berupa pelatihan pada penelitian ini menunjukkan bahwa dari proses refleksi, berbagi dan diskusi tersebut membuat tiap peserta menyadari bahwa mereka tidak merasakan pengalaman buruk sendirian. Peserta juga dapat mengetahui bahwa wanita dengan disabilitas fisik lain juga merasakan pengalaman yang cukup berat dan berbeda-beda mengenai keterbatasan kondisi fisik mereka. Mereka juga dapat menyadari bahwa terdapat masalah yang lebih berat dibandingkan dengan masalah yang mereka hadapi. Peserta juga dapat saling belajar untuk menghadapi masalah dan dapat memperoleh pencerahan dari masingmasing peserta yang lain. Sehingga peserta dapat merasakan atau menimbulkan tekad yang kuat dalam diri untuk berubah menjadi individu yang lebih baik. 


\section{SIMPULAN DAN SARAN}

Berdasarkan analisis data dan
pembahasan yang dilakukan dalam
penelitian ini maka dapat disimpulkan
bahwa pelatihan kebersyukuran terbukti
dapat meningkatkan kualitas hidup pada
wanita dengan disabilitas fisik. Seluruh
subjek merasakan beberapa perubahan
setelah mengikuti pelatihan kebersyukuran,
diantaranya adalah merasa lebih semangat
dan mulai dapat menerima kondisi
keterbatasan fisik yang dialami, lebih
tenang dan dada terasa lega, dapat
mengontrol emosi menjadi lebih positif,
mampu mengidentifikasi hikmah dari segala kesulitan sehingga dapat mensyukuri nikmat dari Allah SWT sehingga ibadah kepada Allah menjadi lebih intens serta dapat percaya diri untuk memulai komunikasi dengan orang lain. Bagi peneliti selanjutnya diharapkan untuk dapat melakukan pemberian tugas rumah untuk monitoring harian kegiatan peserta serta perbuatan syukur dan dampak yang dirasakan setelah dilaksanakan sehingga hasil yang diharapkan dapat lebih optimal serta juga perlu mempertimbangkan faktorfaktor yang mempengaruhi kualitas hidup yang lain seperti usia, jenjang pendidikan dan lain-lain.

\section{DAFTAR PUSTAKA}

Al-Jauziyyah, I.Q. (2010). Sabar dan syukur: menguak rahasia di balik keutamaan sabar dan syukur. Semarang: Pustaka Nuun

Alexander C. (2014). Psychiatric morbidity following disaster: Epidemology, Risk and protective factors. University of Adelaide Australia

Arief, M. F., \& Habibah, N. (2015). Pengaruh strategi aktivitas (bersyukur dan optimis) terhadap peningkatan kebahagiaan pada mahasiswa S1 pendidikan guru sekolah dasar. Seminar Psikologi dan Kemanusiaan UMM.

Ariyulinda, N. (2014). Efektivitas pelaksanaan undang-undang nomor 4 tahun 1997 tentang penyandang cacat. Jurnal Ilmiah Hukum. 5 (1), 91-105

Azwar, S. (2013). Penyusunan skala psikologi (edisi kedua). Yogyakarta: Pustaka Pelajar
Bastaman, H. (2007). logoterapi: psikologi untuk menemukan makna hidup dan meraih hidup bermakna. Jakarta: Penerbit Raja Grafind

Billington, Mary \& Mandy, S. (2010). Kegawatan dalam kehamilan persalinan. Jakarta: EGC

Dewanto, W. \& Retnowati, S. (2015). Intervensi kebersyukuran dan kesejahteraan penyandang disabilitas fisik. Jurnal of Professional Psychology. 1 (1), 33-47

Faizah, R. (2018). The effectiveness of patience training to improve the quality of life of people with disabilities in rural Indonesia. Journal of Arts, Science \& Commerce. 9 (1), 179-184

Edwards, T. C, Patrick, D.L. \& Topolski, T. D. (2003). Quality of life of adolescents with perceived disabilities. $J$ Pediatr Psychol. 28 (4) 233-241 
Emmons, R. A. (2007). Thanks! How the new science of gratitude can make you happier. Boston New York: Houghton Mifflin

Emmons, R. A., \& McCullough, M. E. (2003). Counting blessings versus burdens: an experimental investigation of gratitude and subjective well-being in daily life. Journal of Personality and Social Psychology. 84 (2), 377389.

Fitriana, N.A \& Ambarini, T.K. (2012). Kualitas hidup pada penderita kanker serviks yang menjalani pengobatan radiotrapi. Jurnal Psikologi klinis dan Kesehatan Mental. 1 (2) 123-129

Fitriyah, L., \& jauhar, M. (2014). Pengantar psikologi klinis. Jakarta: Prestasi Pustaka

Froh, J.J., Kashdan, T.B., Ozimkowski, K., \& Miller, N. (2009). Who benefit the most from a grattitude intervention in children and adolescents? Examining positive affect as a moderator. The Journal of Positive Psychology. 4 (5) 408-422

Froh, J. J., Sefick, W. J., \& Emmons, R. A. (2008). Counting blessings in early adolescents: an experimental study of gratitude and subjective wellbeing. Journal of School Psychology. $46,213-233$.

Hambali, A., Meiza, A., \& Fahmi, I. (2015). Faktor-faktor yang berperan dalam kebersyukuran (gratitude) pada orangtua anak berkebutuhan khusus perspektif psikologi. Psympathic, Jurnal Ilmiah Psikologi. 2 (1), 94 - 101

Handayani, D.Y. \& Dewi, E.D. (2009). Analisis kualitas hidup penderita dan keluarga pasca serangan stroke (dengan gejala sisa). PSYCHO IDEA. $7(1), 35-44$
Hikmawati, E. \& Rusmiyati, C. (2011). Kebutuhan pelayanan sosial penyandang Cacat. Informasi. 16 (01), 17-32

Ishak, F. F. (2007). Hubungan antara rasa syukur dengan kesejahteraan psikologis pada lanjut usia. (Skripsi tidak diterbitkan). Program Studi Psikologi, Fakultas Ilmu Sosial dan Ilmu Politik, Universitas Brawijaya, Malang, Indonesia

Jabbari, M., Shahidi, S. \& Mootabi, F. (2015). Effectiveness of group intervention based on positive psychology in reducing symtoms of depression and anxiety and increasing life satisfaction in adolescent girls. Iranian Journal of Psychiatri and Clinical Psychology. 20 (4), 296-287

Kinasih, A.S. (2010). Penelitian mindfulness untuk meningkatkan kesejahteran psikologis pada remaja difabel fisik. (Tesis tidak diterbitkan). Fakultas Psikologi, Universitas Gadjah Mada, Yogyakarta, Indonesia

Kutner, M.H., C.J. \& Neter, J. (2005). Applied linear regression models. fourth editions. The McGraw-Hill

Makhdlori, M. (2008). Menyikap mukjizat sholat dhuha, Yogyakarta: DIVA

Mangunsong, Frieda. (1998). Psikologi dan Pendidikan Anak Luar Biasa. Depok: LPSP3 Universitas Indonesia.

Mappiare, A. (2010). Pengantar konseling dan psikoterapi. Jakarta: Rajawali

McCullough, M. E., Tsang, J. A., \& Emmons, R. A. (2004). Gratitude in intermedate affective terrain: Links of grateful moods to individual differences and daily emotional experience. Journal of Personality and Social Psychology, 86 (2), 295-309). 
McCullough, M.E., Emmons, R. A., \& Tsang, J.-A. (2002). The grateful disposition: A conceptual and empirical topography. journal of Personality and Social Psychology, 82, 112-127. doi:10.1037/0023514.82.1.112

Nofitri, M. (2009). Gambaran kualitas hidup penduduk dewasa pada lima wilayah di Jakarta. (Skripsi tidak diterbitkan) Universitas Indonesia. Jakarta, Indonesia

Notoadmodjo, S. (2010) Metodologi penelitian kesehatan. Jakarta: Rineka Cipta

Power, M.J. (2003). The world health organization whoqol-100: test of the universality of quality of life in 15 defferent cultural groups world wide. Health Psychology. 18, 495505

Pukeliene, V., Starkauskiene, V. (2011). Quality of life: Factors Determining its Measurenment Complexity. Journal of Inzinerine ekonomika Engineering Economics. 22 (2), 147156.

Primadi, A \& Hadjam, M.N.R. (2010). Optimis, harapan, dukungan sosial keluarga dan kualitas hidup orang dengan epilepsi. Jurnal Psikologi. 3 (2), 123-133

Putri, D. N. R. S., Urbayatun, S., Hayati, E. N. (2017). Gratefulness Training to Improve the Quality of Life for Older People. International Journal of innovative Research and knowladge. 2 (12), 109-116

Raeburn, J., \& Rootman, I. (1998). Peoplecentred health promotion. London: John Wiley \& Son
Romdhon, A, Rahmani, N.N., \& Akbar, P.L. (2012). Pengembangan psychologycal measure of islamic grattitude (PMIG): Ukuran psikologis bersyukur dalam perspektif islam. Program kreativitas mahasiswa penelitian (naskah tidak dipublishkan)

Ryff, C. D., \& Singer, B. H. (1998). The contours of positive human health. Psychological Inquiry. 9 (1), 1-28

Salsabila, F. D. (2017). Faktor-faktor yang mempengaruhi kualitas hidup tenaga kerja penyandang disabilitas di kabupaten Bantul, DI Yogyakarta. (Skripsi tidak dipublikasikan). Fakultas Ekonomi dan Manajemen Institut Pertanian Bogor, Bogor, Indonesia

Sanyata, S. (2010). Teknik dan strategi konseling kelompok. Jurnal Paradigma. 9 (5), 105-120.

Sarafino, E.P., \& Smith, T. W. (2014). Health Psychology: Biopsychosocial interactions. London: John Wiley \& Sons

Seligman, M.E.P., \& Peterson, C. (2005). Character strength and virtues: $A$ handbook and classification. Washington, DC: American Psychological Association

Shertzer, B. E., \& Stone, S. C. (1980). Fundamentas of Counseling. Boston; MA Houghton Miflin Company

Sugiyono. (2011). Metode penelitian kuantitatif, kualitatif dan $R \& D$. Bandung: Afabeta

Sukaton, A. (2011). Implementasi program rehabilitasi disabilitas fisik; studi di pusat rehabilitasi terpadu penyandang cacat provinsi D.I. Yogyakarta. (Tesis tidak dipublikasikan). Universitas Gajah Mada, Yogyakarta, Indonesia 
Watkins, P.C., Woodward, K., Stone T., dan Kolts, R.L. (2003). Gratitude and happiness: Development of a measure of gratitude and relationship with subjective wellbeing. social Behavior and Personality. 31 (5), 431-452

WHO. World Health Statistics (2014): World Health Organization

Widjopranoto, R., Sumarno, S. (2004). Potensi penyandang cacat tubuh di Provinsi Jawa Timur (studi kasus Kabupaten Blitar). Media Informasi Penelitian Kesejahteraan Sosial. 179, 3-23.
Wood, A. M., Maltby, J., Gillett, R., Linley, P. A., \& Joseph, S. (2008). The role of gratitude in the development of social support, stress, and depression: Two longitudinal studies. Journal of Research in Personality, 42, 854-871.

Yenny \& Herwana, E. (2006). Prevalensi penyakit kronis dan kualitas hidup pada lanjut usia di Jakarta Selatan. (Tesis tidak diterbitkan). Universitas Trisakti, Jakarta, Indonesia 
Desta Israwanda, Siti Urbayatun \& Elli Nur Hayati 